\title{
Relative Values: Gendering Time and Space
}

\author{
ALISON FINDLAY \\ Lancaster University
}

Cet article montre que les hommes des débuts de la modernitéétaient plus près des liens radicaux d'Einstein entre le temps et l'espace, que les scientifiques modernes d'après Newton. L'écriture offrait aux hommes et aux femmes un accès à un espace imaginaire au-delà du temps chronologique, et ainsi, à des possibilités de renégocier leur position relative dans le cadre de ces limites très réelles. Dans un deuxième temps, on se penche sur la relativité de l'espace et du temps en tant que produits de pratiques sociales et historiques. On y discute donc de deux scènes de la pièce Richard III afin d'intervertir les perceptions courantes de la femme en tant que confinée à un espace intérieur, et de l'homme comme se mouvant plus librement dans l'espace-temps. On explore comment les pratiques spatiales des débuts de la modernité soulèvent de nouvelles questions au sujet des tropes pétrarquiens de l'emprisonnement et de la forme poétique. Dans un troisième temps, l'article examine les motifs de la porte et de la mémoire, considérant la mise en scène de la mort en tant que passage vers un ailleurs, dans la Duchesse de Malfi. La dernière partie de l'article met à profit les descriptions que fait Margaret Cavendish de plusieurs mondes au sein de celui-ci, afin d'émettre en conclusion des parallèles entre la littérature des débuts de la modernité et la théorie des cordes de la science actuelle.

CC enceforth space by itself, and time by itself, are doomed to fade away

1 into mere shadows, and only a kind of union of the two will preserve an independent reality," declared Einstein's teacher, Minkowski. ${ }^{1}$ Einstein's theory of the relativity of time to movement through space shook the modern world by unfixing the absolutes of Newtonian physics. ${ }^{2}$ The interconnected nature of space and time was something already deeply embedded in Western culture, as seen in the tendency to estimate space in units of time (for example "a day's walk") and to spatialize time (as "long" or "short," "always"). ${ }^{3}$ The geographer $\mathrm{Yi}-\mathrm{Fu}$ Tuan has pointed out that measuring time in terms of space, which can 
be more easily comprehended and navigated, offers an illusion of control over the uncertainties of the human lifespan. ${ }^{4}$ Early modern texts offer numerous examples of this phenomenon. Popular medical books spatialize time as part of their prescriptions to assert control over the mysterious, ailing body. To maximize the power of a purge, for example, the patient should "walke up and downe for a good space," and the recipe for an ointment for aches requires one to soak herbs in oil "for the space of a full moneth" and then boil it "for the space of three houres or some what more." ${ }^{5}$ Personal, Biblical, and historical time is also measured in space, such as in George Abbot's funeral sermon on the Earl of Dorset which, to show the "transitorie" nature of life, describes it in terms of tenancy: "The old house must to the ground, that so the tenant of it may ascend unto God by a kinde of remove till the building be new repaired." In Shakespeare's 2 Henry VI, the King's futile attempt to govern the fluctuating desires of his wife and his subjects is shown in his words to Suffolk: "If after three days' space thou here beest found / On any ground that I am ruler of / The world shall not be ransom for thy life" (2 Henry VI 3.2.297-99).7 Time is spatialized alongside territory.

Connecting time and space physically rather than metaphorically, as Einstein did, was probably more easily comprehensible to early modern subjects than to Einstein's contemporaries. The thought of relative simultaneity - that in order to accommodate the pasts, presents, and futures of every different entity in motion in the universe, events in the past and future have to be just as real as events of the present, with no division between them - is difficult to understand from an earth-bound, human perspective. The religious belief of early modern subjects, such as the writer Henry Vaughan, opened a different way of viewing time and space, however:

I saw Eternity the other night,

Like a great Ring of pure and endless light,

All calm, as it was bright,

And round beneath it, Time in hours, days, years

Driven by the spheres

Like a vast shadow moved, in which the world And all her train were hurled. ${ }^{8}$ 
For Vaughan, eternity is a place beyond the movement that dictates chronological time: hours, days, years. Horace H. Underwood pointed out that Vaughan's poetry frequently configures the temporal polarity of time and eternity as a spatial polarity between heaven and the world, reading the recurrence of vertical movement as a metaphor for human ascent to heaven after death. ${ }^{9}$ Indeed, Vaughan's poem goes on to present an unrequited lover, a corrupt statesman, and a miser as examples of the vanity of "All that is in the world" which will, according to the Gospel of John, pass away unlike the will of God "which abideth for ever" (1 John 2:16-17). In a more literal reading, Vaughan's lines, above, represent Einstein's four-dimensional space-time: a universe "Driven by the spheres," a shadow simultaneously encompassing everything "hurled" and moving simultaneously within hours, days, years, human lives, and all of postlapsarian existence. ${ }^{10}$ Modern physics would cite the moment of the Big Bang as the point in which time and space are "hurled" into existence. Heaven, on the other hand, is outside time and space, "like a great Ring of pure and endless light" that exists in a dimension beyond the scope of human comprehension. As Saint Augustine pointed out, "It is idle to look for time before creation, as if time can be found before time. If there were no motion of either a spiritual or corporeal creature by which the future, moving through the present, would succeed the past, there would be no time at all.... We should therefore say that time began with creation rather than that creation began with time." ${ }^{11}$ Even if an existence beyond space-time cannot be understood, Vaughan's poem shows that it appealed to the imagination.

It was a dimension of possibility for both male and female writers. In Rachel Speght's poem "The Dreame" the speaker is also granted a glimpse of eternity, which, like Vaughan, she perceives in spatial terms:

By appoyntment of supernall power,

By instrumentall meanes me thought I came

Into a place most pleasant to the eye,

Which for the beauty some did Cosmus name,

Where stranger-like on everything I gaz'd

But wanting wisedom was as one amaz'd. ${ }^{12}$

The dreamer in Speght's poem cannot comprehend the strange cosmos where past, present, and future are experienced simultaneously. She is "as one amazd," 
lacking the divine wisdom to understand the beauty that she sees. Nevertheless, here she experiences a space in which woman's "will, mind and power" are given free range to rewrite, in positive terms, Eve's sinful desire for knowledge. The new place in which she finds herself is set apart from the space-time where woman is subjected as the weaker vessel. It transcends Biblical and cultural history. The speaker explores "Eurdition's garden" and Truth informs her: "wherefore shall / A woman have her intellect in vaine / Or not endeavour Knowledge to attaine" (p. 5). However, Speght's literary persona is always conscious that her sojourn to this dimension is exceptional and temporary:

Yet know I not, nor can I give a guesse

How short a time I in this place shall spend.

For that high power which sent me to this place

Doth onely know the period of my race.

As if to point up the difference between chronological space-time and kairotic transcendence (where past, present, and future co-exist), she returns from her dream-vision of the cosmos back to earth to discover that her mother has died. Speght's speaker laments, "The roote is kild, how can the boughs but fade?" (p. 11). It looks as though the stifling legacy of Eve is inescapable, yet the poem ends with the speaker's determination to challenge death's control through writing. She promises to "show how it to tyrranize began" (p. 11) and does so in an extensive memorandum on the inevitability but temporary nature of death, offering in passing another positive interpretation of Eve as a heroine who broke the serpent's hold over man by inaugurating the line of progeny culminating in Christ. Speght's writing indicates that both men and women of the early modern period were able to use writing to re-negotiate the relationship between time and space and their own relative positions within its very real boundaries.

In the lived world, as Neil Smith points out, "the relativity of space becomes not a philosophical issue but a product of social and historical practice."13 To begin assessing how the production of space and time operated in early modern writing with reference to wider social practices, the principles recommended by David Harvey for human geography offer useful starting points. In addition to recognizing that "each social formation constructs objective conceptions 
of space and time sufficient unto its own needs and purposes of material and social reproduction" it is crucial to remember that "the exact manner in which concepts of space and time operate in social reproduction is... subtle and nuanced." ${ }^{14}$ Thus, to take an obvious early modern example of gendered space: while Biblical authority, legal practices, and a vast number of conduct books decreed that woman's place was inside the household and man's was "abroad" in public arenas, the ways in which those venues were constructed and inhabited by early modern subjects was far more complex. To begin with, the household was a social rather than a private space in the modern sense of the word: open to a range of extended family members and non-relatives as the centre of domestic work of various types. In large houses, managing the estate and its employees was frequently a task undertaken by wives, mothers, and daughters. Sara Mueller has argued that the staging of domestic work in progress entertainments such as those mounted by Elizabeth Russell and Lord and Lady Egerton "strove to legitimate, value and give credit to the power of women's labor on the country estate." ${ }^{15}$ The young women who worked as domestic servants in both large and small houses (representing about 60 percent of the nation's women aged between 15 and 24) were often regarded as "transient, potentially disruptive and sexually available," rather than safely enclosed in a domestic arena. ${ }^{16}$ Some forms of work, such as selling goods in shops, markets, and on streets and quaysides, moved women into open, public spaces.

The imprisonment of women behind the walls of their houses is thus a metaphor belied by the lived practices of early modern subjects, as is shown most graphically in the space-time dynamic of Act 4 of Shakespeare's Richard III. Queen Elizabeth, the Duchess of York, and the other women of the play are excluded from the Tower and the palace to an open arena where they engender the downfall of the tyrant-king. Being outside the walls appears, paradoxically, a form of constraint in Act 4 Scene 1. The scene has a futuredirected impetus that is silently embodied on stage by the young figure of Clarence's daughter. Queen Elizabeth, the Duchess of York, Lady Anne, and Clarence's daughter are moving forward to the Tower to see the princes, and all three women are angered by the way "bounds" have been set in very solid form between them and the sons and heirs who represent their future. "I am their mother, who shall bar me from them?" asks Elizabeth at the walls of the Tower (4.1.20-21). Stanley enters "in haste" to bring Anne to her coronation "one hour hence," a future depicted as harshly constricting in Anne's vision 
of the crown as an "inclusive verge" that will burn into her head "with redhot steel and sear me to the brains" (4.1.28-32 and 59-61). For Elizabeth the news is suffocating; she exclaims, "cut my lace asunder that my pent heart / May have some hope to beat" (4.1.33-34). She inverts conventional images of maternal care in warning Dorset that her identity carries a death sentence for her children in "this slaughterhouse." The only hint of escape is to another country - France - and to the Earl of Richmond (4.1.41-43). The Duchess of York magnifies the claustrophobic nightmare of the "accursed womb" as "bed of death" (4.1.53) and the image of women cut off from their creative potential is materialized in Elizabeth's closing lines from the Folio text:

Pity, you ancient stones, those tender babes

Whom envy hath immured within your walls

Rough cradle for such little pretty ones,

Rude, ragged nurse, old sullen playfellow

For tender princes: use my babies well

So foolish sorrow bids your stones farewell.

Elizabeth's apostrophe to the walls of the Tower looks forward to a tragic future she has already guessed. Her freedom is, as yet, felt only as exclusion; it is not until the temporal shift of Act 4 Scene 4 that the women are able to use their position as outsiders to exercise their control over past, present, and future.

The death of the princes, and of the future, releases Elizabeth and the Duchess of York from the "brief abstract and record of tedious days" (4.4.28) that mark chronological time. Richard's exchange over the clock at the end of Act 4 Scene 2 had pointedly illustrated his mastery of linear narratives of succession. By contrast, Margaret's ghost-like voice which opens Act 4 Scene 4 outside the walls of Richard's palace inducts the trinity of weeping widows into a spacetime where events of the past, present, and future co-exist as immanent, shared events. Their communion prepares them to exploit what might be called, using Kristeva's term, "women's time": a sentient awareness of cyclical rhythms based on female proximity to the experiences of birth and death that aligns them with extrasubjective, cosmic time and produces jouissance. ${ }^{17}$ At the flourish marking Richard's entrance, his progress is pointedly "intercepted" (4.4.137) by his mother the Duchess of York, who begins the process of aborting him through 
references back to his birth. The birthroom is an all-female space governed by "women's time" in the generations of experience that are "confined" or concentrated and literally brought to bear on the present moment of labour. Time moves very differently for the men denied access to the birthroom, as during the long night of Queen Anne's labour in All Is True (5.1), for example. In Richard III the Duchess of York's account of Richard's monstrous origin, her labour in "torment and in agony" (4.4.164), and the cries of the midwife and childbed attendants that "he is born with teeth!" (3 Henry VI 5.6.70-80) carry an overdetermining female authority and spread like a narrative web across the generations to entrap the bottled spider.

Once the Duchess has spoken her "most heavy curse" to Richard (4.4.188), Elizabeth is able to re-configure the space of the womb in more creative terms. At first, however, she must reappropriate it. Richard's attempt to redeem his brutality in killing Elizabeth's sons is to "bury them" in the womb of her daughter, Princess Elizabeth. He imagines it as a "nest of spicery" where the murdered princes "will breed / Selves of themselves," supposedly to her - but more realistically to his - "recomfiture" (4.4.353). However, in the hands of Queen Elizabeth, now semi-detached from the palace and the exigencies of chronological time, it becomes a wandering womb. She agrees to the match but surreptitiously arranges an alternative marriage between the princess and Richmond, thus reanimating the reproductive womb as a space-time that can rewrite history. She confounds Richard's oath by "the time to come," telling him "that thou hast / Misused ere used” (4.4.326-27). While Richard flamboyantly threatens "Death, desolation, ruin and decay" (4.4.340), it is Elizabeth who can change colours with the chameleon and quietly found the Tudor dynasty with a female line: Princess Elizabeth of York, wife of Henry VII, being the grandmother for whom Elizabeth I was named. The play celebrates this female-directed dynasty beneath the bluster of Richard's rhetoric. Although he does not know it, the self-defining hero is already imprisoned in a cyclical "Elizabethan" history.

Evidence that men could be imprisoned as much as women and write about that feelingly is presented in Molly Murray's essay, in this issue, which discusses the Devonshire Manuscript poems of Lady Margaret Douglas and Sir Thomas Howard, written in the Tower of London while imprisoned by attainder. It is salutary to find correspondences in the verse of these two writers and to compare their material experiences of imprisonment with the tropes of confinement typical of Petrarchan tradition, such as those used by the later 
courtier poets Philip Sidney and Lady Mary Wroth. As Murray notes, Douglas and Howard's conventional uses of captivity to love are an indictment of the "charged intersection of power, gender, and imprisonment" (p. 19) under Henry VIII's rule, demonstrated most spectacularly in his summary disposal of Anne Boleyn. By reading the poems as a dialogue, Murray encourages us to see common ground between male and female writers.

An examination of how time and space are used in Lady Mary Wroth's work, in comparison to that of male sonneteers, including her uncle, Sir Philip Sidney, supports Murray's view that we need to interrogate the permeability of boundaries - including those between genders - when considering issues of freedom or confinement. Critical writings on Wroth's poems and romances have usefully considered her poetic persona Pamphilia as a gendered re-writing of the Petrarchan lover and the sense of imprisonment he feels. ${ }^{18}$ In Astrophil and Stella, the sonnet sequence by Sir Philip Sidney, the figure of Astrophil famously complains in Sonnet 47 "What, have I thus betrayed my liberty?" only to surrender it again in the final line of the sonnet. ${ }^{19}$ For Wroth's female speaker, it has been argued, the tropes of helplessness, enforced passivity and frustration give voice to a lived experience shared by early modern women. Pamphila laments her enthrallment to love: "Must I be still, while it my strength devours, / And captive leads me prisoner, bound, unfree?" Like Astrophil, she ends by resigning herself to it again: "I love, and must, so farewell liberty." ${ }^{20}$ Pamphilia’s unrequited love for Amphilanthus has been read autobiographically with reference to Wroth's love for her cousin, William Herbert. It is, however, somewhat difficult to read Wroth's images of imprisonment literally, or in specifically gendered terms, when we consider her life experiences "abroad." She spent time with her family in Flushing, where her father was governor, and was actively involved with the culture of the Stuart court from the family's London residence at Baynard's Castle. After the death of her husband in 1614, Wroth undertook careful management of the estates at Durrance and Loughton Hall. ${ }^{21}$

For male writers like Thomas Howard, Walter Ralegh, or Philip Sidney, the tropes of confinement may have been even more resonant than they were for women sonneteers. In Julius Caesar Cassius defines loss of civic space as particularly shameful for men of noble blood: "Now is it Rome indeed and room enough / When there is in it but only one man" (1.2.157-58). Thomas Howard's detainment in the Tower under the tyranny of Henry VIII brings home to us the fact that material and cultural confinement made the court an oppressive 
place for noble subjects of both genders. Murray's essay thus prompts us to consider the use of space and time in women's Petrarchan poetry as part of the game of courtly political manoeuvre and as part of a dialogue about literary convention. Wroth, for example, playfully ventriloquizes her uncle's sonnet 47 in the Urania with both male and female voices. First, Pelarina complains that, captive to love, she "could but like a poore miserable Poet confesse my selfe in Rime" and recites: "Did I boast of Liberty? / Twas an insolency vain: / I do only look on thee, / And captive am again." Later Prince Leurinius riffs on Sidney's sonnet again when he sings "Have I lost my liberty, / And my self, and all, for thee / O Love?"22 Wroth's concern with her own poetic voice is heard through Pamphilia, whose protestations are as artful as they are passionate:

No time, no room, no thought nor writing can

Give rest or quiet to my loving heart

Or can my memory of fancy scan

The measure of my still renewing smart.

At a metadiscursive level, the speaker apologizes for the seemingly interminable flow of words through which women's love is traced in the Urania. Her thoughts, feelings, and writing flow across time and space, always ready to be reactivated in the present by the reading subject. Wroth, like Shakespeare the sonneteer, registers an afterlife for her writing and the emotions it expresses. Personal experiences of love exist as part of a continuum "until the world come to a final end," an early modern version of the Big Crunch (which, according to some modern theories, will follow the expansion of the universe caused by the Big Bang). Only then will human subjects be able to "discern" Love's power to transcend the vicissitudes of chronological space-time (p. 124). A more elaborate cosmic metaphor is used at the end of Book I of the Urania where a shepherd sings that Love existed "before the world did move" appearing "in Chaos" when "nothing was, yet he seemed clear." ${ }^{23}$ Wroth's extravagant metaphors point to the scope of artistic expression to rewrite the space and time of lived experience in utopian terms, something taken up in the two discussions of Margaret Cavendish's work in this issue by Marina Leslie and Jennifer Park.

The permeability of prison walls, which are evidenced materially in Murray's essay and poetically in tropes of incarceration used to release passions 
for display, encourages us to think further about the permeability of poetic forms as well. Diana Henderson argues in her essay in this issue that we should break out of the rigid metrical definitions of "the sonnet" as a tight, fourteenline structure and adopt a more descriptive aesthetics that opens up the sonnet to include other types of lyric. Elsewhere, Rudolph Almasy has pointed out how the songs interspersed in manuscript versions of Sidney's Astrophil and Stella give Stella's voice a chance to emerge very fully, perhaps through Mary Sidney's editorial intervention, while their excision or removal to the end of the sequence in Q1 (1591) may have been a result of early editors and readers seeking to define the English sonnet sequence in exclusively male terms. ${ }^{24}$ Expanding our critical horizons allows us to appreciate how a wider range of female writers rework Petrarchan ideas for their own purposes. A consideration of performance makes the form even more fluid. Regardless of the gender of its author, a song or sonnet can be sung or spoken by a male or female voice, and in that moment of incorporation and expression the piece moves across boundaries of time, space, gender, and class. The circulation of early modern texts through print, manuscript, and memory moves these writings to speak directly to and for present-tense, lived, spatial experience. This has important implications for our own presentist reading and teaching of archival material.

Mary Queen of Scots's motto "In my end is my beginning" alerts us to another artful manipulation of conventional space-time: the redefinition of death as an opening..$^{25}$ John Taylor's Urania or His heavenly muse (1616) offered a conventional message by urging readers to "do Good with them whilst thou hast time and space" in order to make a positive account of one's performance in the "transitorie race" when presented for divine judgment. ${ }^{26}$ Retha Warnicke and David Cressy have both shown how the seemingly private moment of death was, in early modern England, a public, communal event. As with births, ceremonies surrounding the deathbed were attended and witnessed by members of the community as well as close and more distant kin, though in this case men and women were both involved. Warnicke has argued that women were the particular focus of cultural attention at such moments. Although conduct books for women repeatedly warned about the moral dangers of displaying oneself in public, the dying woman was a living spectacle, her bed "was a kind of stage from which to act out the last role of her life" and demonstrate her virtue and preparedness for death "in the tradition of the ars moriendi." ${ }^{27}$ Femke Molekamp's essay, here, shows how transcribed or narrated accounts of the deathbed in printed funeral 
sermons extended the scope of the woman's farewell performance to a much wider audience across space and time. Molekamp notes the didactic purpose behind the sermons' display of exemplary patterns of female virtue for other women to read and imitate. At the same time, she suggests that the domestic, enclosed spaces prescribed for female devotion "might afford secret, unknowable mystical union with Christ" (p. 59).

To what extent can the deathbed performance be appropriated by female participants to create room of one's own beyond or within the didactic space-time framework? The display of Anne Frankford's adulterous and then penitent, dying body in Heywood's A Woman Killed With Kindness does little more than offer a searing critique of the patriarchal "kindness" or hospitality that encouraged the adultery and then left Anne as a shadow of herself, with no viable place or time to exist. Her wasting body advertises waste. ${ }^{28}$ Katherine of Aragon's exemplary death is staged in spectacular fashion in All Is True, though its Catholic iconography and the character's appeal to "Spirits of peace" not to "leave me here in wretchedness behind ye" (4.2.83) do give a subversive edge to the play's celebration of Protestant nationhood. The Duchess of Malfi's death holds out more radical possibilities. Recognizing that "heaven-gates are not so highly arch'd / As princes' palaces," the Duchess kneels to be strangled (4.2.230-31) ${ }^{29}$ As well as being an expression of exemplary humility, in spatial terms this is also a subversive act and a fitting end to a wilful life that transgresses boundaries of class and gender. The doorway she constructs through the physical movements of the actor is obviously too small for the princes, her brothers, to pass through, so a conventional act of female piety (which recalls the alabaster figure kneeling at her husband's tomb) disguises the entrance to a world elsewhere: an afterlife or space of possibility in which the female subject holds agency. Nor is this simply a utopia or heaven, removed from everyday practice. The Duchess points out:

I know death hath ten thousand several doors

For men to take their exits; and 'tis found

They go on such strange geometrical hinges

You may open them both ways. 
As well as cueing the return of the repressed, active female voice in the ghost that haunts the final act of the play, this rather curious digression speaks directly to female spectators at the immediate moment of performance. The theatre, like the deathbed, is an exceptional moment outside normal space-time that allows doorways to go on strange geometrical hinges, backwards and forwards. "You" who have witnessed this extraordinary life story and deathbed can reanimate the radical possibilities opened up on entering the doors of the theatre, and take them back - mentally, emotionally, and maybe even practically in the everyday space-time which operates on this side of the doorway.

As Lloyd Kermode's analysis of King Leir cleverly demonstrates, space and time are warped in multifaceted ways in the enclosed circumference of the theatre. While the wooden $\mathrm{O}$ is "nothing," a fiction, it simultaneously reaches out culturally and emotionally to an infinite number of other spaces and times in the experiences of each group of spectators at each performance. Individual examples of lived spatial-temporal practice jostle with shared knowledge of other performances in the same theatre and, more widely, with shared traditions passed down from generation to generation in the form of rituals and ceremonies designed to mark moments of change in human life (births, betrothals, marriages, deaths). Such heightened moments of social interaction are like performances in that they usually involve a prescribed script of some kind, a company of participants with clearly defined roles and a precise orchestration of spatial practice between participants and objects for the duration of the event. On stage, the fictional representation of such events before a community of spectators retains the power to forge connections between the moment of enactment and equivalent moments in the memories or imagined futures of individuals. In this sense it resembles the singularity in theories of creation: the moment of the Big Bang at which there is no volume but infinite density, something that our laws of physics cannot understand. Similarly, we need more detailed analysis to explore how such fictional staged moments might act as dramatic "wormholes" to transport texts and audiences into parallel worlds.

The mystic tradition and the writings of Rachel Speght, William Vaughan, Francis Godwin, and Margaret Cavendish all attest to early modern readiness to imagine parallel worlds and realize them in writing. The essays by Park and Leslie, mentioned above, offer trenchant examinations of the ways time and space intersect freely with surprisingly modern resonance in texts like The Blazing World. The most well known examples of Cavendish's multiverse theory 
are the poems "Of Many Worlds in this World" and "A World in An Eare-Ring," where she imagines "in this World, may many Worlds more be / Thinner and lesse" and "not subject to our Sense." ${ }^{30}$ Although Cavendish's "fancies" earned her a reputation for madness in seventeenth-century England, her proposal of alternative realities complete with planets, weather, animals, and plants, unrealized in the speaker's space-time, bears relation to versions of string theory in contemporary quantum physics. In The Grand Design (2010), for example, Stephen Hawking and Leonard Mlodinow argue that multiple universes arise naturally from physical law, though only those compatible with our own are brought into reality by our presence in space and time, making us "in a sense, the lords of creation" and thus not requiring "the intervention of some supernatural being or god." 31

For physicists such as Russell Stannard, and for most early modern subjects, however, any doorway to a dimension beyond our own space-time leads to a divine power beyond the compass of our apprehension or understanding. ${ }^{32}$ The incarnation "open set the dore / To Eternall life, neer seene, nor knowne before," as Aemelia Lanyer put it. ${ }^{33}$ Einstein likewise believed in the presence of an incomprehensible but "superior reasoning power, which is revealed in the incomprehensible universe." ${ }^{34}$ In spite of current media excitement about proof of a so-called "God particle," particle physicists see the Higgs boson as part of a much wider field of opportunity provided by the Large Hadron Collider at the CERN laboratory. As Jon Butterworth remarked, "this machine opens a door to a new room, but we've got to have a good look around in that new room." Proof of the Higgs boson is "a very important question but it's far from the only one, ${ }^{35}$ a view that would, no doubt, have earned Einstein's approval. We are therefore in a good position to appreciate an early modern perspective in which "time travels in divers paces with divers persons" (As You Like It 3.2.281-82) not just at a subjective level but on a cosmic scale. For early modern men and women, as for Einstein, the relativity of time and space in a divinely ordered universe mysteriously accommodates the simultaneity of past, present, and future events alongside the power of human free will and reason. It was through such a panentheistic lens that people negotiated temporal and spatial pathways through their social and material worlds. Uncertainties caused by the changing protocapitalist economy and the unpredictability of health made one's relative position fluid. Though bound by their role in terms of class and gender - literally bound as apprentices or in service, in networks of obligation to patrons, 
to family members, to heirs, to subjects and dependents - early modern subjects also saw their "place" as a fixed term contract, measured ultimately by mortality. Another existence was always present and, arguably, early modern subjects - working through their spiritual, intellectual, political, theatrical, or literary apprenticeships - looked forward through the doorway of mortality into new spaces of possibility.

\section{Notes}

1. Quoted in A. Pais, Subtle Is the Lord: The Science and the Life of Albert Einstein (Oxford: Oxford University Press, 1982), p. 152.

2. For a summary of Einstein's theory that time must be measured according to movement though space in relation to the speed of light see Russell Stannard, "God in and beyond Space and Time," in In Whom We Live and Move and Have Our Being: Panentheistic Reflections on God's Presence in a Scientific World, ed. Philip Clayton and Arthur Peacocke (Michigan: Eerdmans Publishing, 2004), pp. 109-20 (pp. 110-12).

3. B. L. Whorf, "The Relation of Thought and Behavior in Language," in Collected Papers on Metalinguistics (Washington: Foreign Services Institute, 1952), pp. 27-93.

4. Yi-Fu Tuan, "Space and Place: Humanistic Perspective," in Philosophy in Geography, ed. S. Gale and G. Olsson (Dordrecht, Boston and London: Reidel Publishing, 1979), pp. 387-427 (pp. 391-93).

5. A.T., A Rich Store-House or Treasury for the Diseased (London, 1596), sigs. C3v and D3.

6. George Abbot, A Sermon Preached at Westminster, May 261608 at the Funerall Solemnities of the Right Honorable Thomas Earle of Dorset (London, 1608), pp. 2 and 6-7.

7. All quotations from Shakespeare are from The Norton Shakespeare, ed. Stephen Greenblatt, Walter Cohen, Jean E. Howard, and Katharine Eisaman Maus, $2^{\text {nd }}$ ed. (New York and London: W. W. Norton \& Company, 2008).

8. Henry Vaughan, Complete Poems, ed. Alan Rudrum (Harmondsworth: Penguin Classics, 1967), pp. 227-28 (p. 227).

9. Horace H. Underwood, "Time and Space in the Poetry of Vaughan," Studies in Philology 69 (1972), pp. 231-41 (p. 237). 
10. Fredson Bowers, "Henry Vaughan's Multiple Time Scheme," Modern Language Quarterly 23 (1962), pp. 291-96, noted the simultaneity of events and time spans referred to by Vaughan's metaphors of darkness and night, as Underwood remarks (p. 233).

11. Cited in Stannard, "God in and beyond Space and Time," p. 118.

12. Rachel Speght, Mortalities Memorandum with A Dreame Prefixed, imaginarie in manner; reall in matter (London: Edward Griffin for Jacob Bloome, 1621), p. 1.

13. Neil Smith, Uneven Development: Nature, Capital and the Production of Space (Oxford: Basil Blackwell, 1984, reprinted University of Georgia Press, 2008), p. 107.

14. David Harvey, "Between Space and Time: Reflections on the Geographical Imagination," Annals of the Association of American Geographers 80.3 (1990), pp. 418-34 (p. 419).

15. Sara Mueller, "Domestic Work in Progress Entertainments," in Working Subjects in Early Modern English Drama, ed. Michelle M. Dowd and Natasha Korda (Farnham: Ashgate Publishing, 2011), pp. 145-59 (p. 150). This volume offers an excellent overview of changing patterns of work and its representation.

16. See Sara Mendelson and Patricia Crawford, Women in Early Modern England 1550-1720 (Oxford: Oxford University Press, 1998), pp. 92-94 and Michelle M. Dowd, "Desiring Subjects: Staging the Female Servant in Early Modern Tragedy," in Working Subjects in Early Modern English Drama, pp. 131-44 (p. 134).

17. Julia Kristeva, “Women's Time," Signs 7.1 (1981), pp. 13-35, p. 16.

18. See, for example, Josephine Roberts, "Lady Mary Wroth's Sonnets: A Labyrinth of the Mind," Journal of Women's Studies in Literature 1 (1979), pp. 319-29; Barbara Kiefer Lewalski, "Writing Women and Reading the Renaissance," Renaissance Quarterly 44.4 (1991), pp. 789-821; Naomi Miller, Changing the Subject: Mary Wroth and the Figurations of Gender in Early Modern England (Lexington: University of Kentucky Press, 1996), pp. 29-40; and Mary Moore, "The Labyrinth as Style in Pamphilia to Amphilanthus," Studies in English Literature 1500-1900 38.1 (1998), pp. 109-25.

19. Sir Philip Sidney, Selected Writings, ed. Richard Dutton (London: Routledge, 2002), p. 52.

20. Poems of Lady Mary Wroth, ed. R. E. Pritchard (Keele: Keele University Press, 1996), p. 37. All quotations are from this edition.

21. See Margaret P. Hannay's fine biography Mary Sidney, Lady Wroth (Farnham: Ashgate, 2010), esp. pp. 170-78. 
22. Lady Mary Wroth, The Countess of Montgomery's Urania (London, 1621), Book IV, pp. 453 and 547-58.

23. Poems of Lady Mary Wroth, p. 141 (taken from Urania, pp. 144-45).

24. Rudolph P. Almsay, "Stella and the Songs: Questions about the Composition of Astrophil and Stella," South Atlantic Review 58.4 (1993), pp. 1-17 (p. 9).

25. Robin Bell, ed., Bittersweet Within my Heart (San Francisco: Chronicle Books, 1992), p. 84.

26. John Taylor, Taylors Vrania, or His heauenly muse With a briefe narration of the thirteene sieges, and sixe sackings of the famous cittie of Ierusalem (London, 1616), sig. D2v.

27. See Retha Warnicke, "Eulogies for Women: Public Testimony of Their Godly Example and Leadership," in Attending to Early Modern Women, ed. Susan Dwyer Amussen and Adele Seeff (London: Associated University Presses, 1998), pp. 168-80 (p. 170) and David Cressy's "Response: Private Lives, Public Performance and Rites of Passage" in the same volume, pp. 187-97.

28. Thomas Heywood, A Woman Killed with Kindness, ed. Brian Scobie, New Mermaids (London: A \& C Black, 1985), Scene xvii, lines 40-140.

29. John Webster, The Duchess of Malfi, ed. John Russell Brown, Revels Plays, 2nd edition (Manchester: Manchester University Press, 2009).

30. Margaret Cavendish, Poems and Fancies (London, 1653), pp. 44-46.

31. Stephen Hawking and Leonard Mlodinow, The Grand Design (London: Bantam Press, 2010), pp. 18-19. M Theory argues that there are many different internal spaces (the curling up of extra dimensions into tiny, invisible spaces), allowing for different universes, each with its own laws (p. 118).

32. See Russell Stannard, The End of Discovery (Oxford University Press, 2010) and "God in and beyond Space and Time," cited above, note 2.

33. Susanne Woods, ed., The Poems of Aemeilia Lanyer: Salve Deus Rex Judaeorum (Oxford: Oxford University Press, 1993), p. 46.

34. Yehuda Elkana, "Einstein and God," in Einstein for the $21^{\text {st }}$ Century: His Legacy in Science, Art and Modern Culture, ed. Peter L. Galison, Gerard Holton, and Silvan S. Schweber (Princeton: Princeton University Press, 2008), pp. 35-47 (p. 36). Einstein's thoughts on religion, "Albert Einsteins gesprochenes Glaubernbekenntnis," have been stated thus:

It was the experience of mystery, even if mixed with fear, that engendered religion. A knowledge of the existence of something we 
cannot penetrate, our perceptions of the profoundest reason and most radiant beauty, which only in their most primitive forms are accessible to our minds - it is this knowledge and this emotion that constitute true religiosity; in this sense, and in this alone, I am a deeply religious man. I cannot conceive of a God who rewards and punishes his creatures, or has a will of the kind that we experience in ourselves.

Quoted in Max Jammer, Einstein and Religion: Physics and Theology (Princeton: Princeton University Press, 1999), p. 73.

35. Professor Jon Butterworth, interviewed by Tom Feilden, science correspondent, in "Is There More to CERN than Higgs?" Today, British Broadcasting Corporation, 13 March 2012, http://www.bbc.co.uk/news/science-environment-17352453. 
